\title{
MOTIVASI BERMAIN BOLA BASKET SISWA SMA NEGERI 12 MAKASSAR
}

\author{
Edy Gunawan \\ Universitas Nahdlatul Ulama Sulawesi Tenggara \\ email: edybarca10@gmail.com
}

\begin{abstract}
ABSTRAK
Penelitian ini bertujuan untuk memperoleh jawaban atas permasalahan: 1). Bagaimana motivasi bermain bola basket siswa SMA Negeri 12 Makassar. Dalam penelitian ini menggunakan metode survei yaitu penelitian yang mengambil sampel dari suatu populasi dan menggunakan kuesioner sebagai alat pengumpulan data yang pokok. Penelitian ini bersifat deskriptif dengan variabel mandiri. Populasi dan sampel adalah siswa SMA Negeri 12 Makassar dipilih secara random sampling diperoleh sampel sebanyak 30 orang. Teknik analisis data yang digunakan deskriptif prosentase. Berdasarkan hasil analisis data dapat disimpulkan sebagai berikut: 1). motivasi dalam bermain bola basket siswa SMA Negeri 12 Makassar menunjukkan kategori sedang $(71,66 \%)$. Hal tersebut karena dipengaruhi oleh faktor-faktor yang dapat mempengaruhi motivasi untuk bermain bola basket seperi sarana dan prasana, media pembelajaran, dukungan dari keluarga, dan lain-lain.
\end{abstract}

Kata Kunci: motivasi, bermain, bola basket.

\section{ABSTRACT}

This study aims to obtain answers to problems: 1). How is the motivation to play basketball in Makassar 12 High School students. In this study using a survey method that is research that takes samples from a population and uses a questionnaire as a basic data collection tool. This research is descriptive with independent variables. The population and sample were Makassar State Senior High School 12 students selected by random sampling obtained a sample of 30 people. Data analysis technique used descriptive percentage. Based on the results of data analysis it can be concluded as follows: 1). motivation in playing basketball in Makassar 12 High School students shows a moderate category (71.66\%). This is because it is influenced by factors that can influence the motivation to play basketball like facilities and infrastructures, learning media, family support, and others.

Keywords: motivation, play, basketball.

\section{PENDAHULUAN (Introduction)}

Dunia olahraga di tanah air menampakkan perkembangan yang makin lama makin mantap baik dalam partisipasi dari segala lapisan masyarakat, maupun dalam prestasi dari segala lapisan masyarakat, maupun dalam prestasi dan penampilan para olahragawannya. Kegiatan olahraga nampaknya mempunyai dampak yang berlipat ganda.

Demikian pula kesadaran masyarakat akan pentingnya berolahraga untuk kesehatan, kesempatan yang makin luas untuk berolahraga, bertambahnya prasarana dan sarana, tumbuhnya perkumpulan-perkumpulan olahraga diseluruh pelosok tanah air, prestasi para olahragawan kita diberbagai pertandingan internasional, serta perbaikan ekonomi dan pembangunan di Negeriara kita telah 
membantu perkembangan olahraga ditanah air, dengan perkembangan yang sangat semakin mantap, baik dalam prestasi, ataupun partisipasi dalam olahraga oleh karena semuanya tidak terlepas dari dorongan atau motivasi yg menunjang baik dari dalam maupun dari luar.

Sejarah permainan bola basket berasal pada Negeriara Amerika, mula-mula Untuk menghilangkan kelesuan olahraga pada musim-musim dingin $D r . L$. $H$ Gullick, Sekretaris dari bagian pendidikan jasmani YMCA(Young means christian Association) Amerika serikat dan ketua pendidikan YMCA internasional, yang sekarang disebut springfield college, di Massachusetts mengkhendaki di ciptakannya suatu permainan yang dapat dimainkan pada waktu musim dingin, menyenangkan, mudah dipelajari, mudah dimainkan dan menghindari permaninan kasar. Dan ditemukanlah permainan bola basket oleh James naismith. Permaianan bola basket pada tahun1891, untuk pertama kalinya dimainkan, dan ternyata mendapat sambutan yang sangat baik.Bola basket masuk ke Indonesia, setelah perang dunia ke-II dibawa oleh perantau-perantau cina dan berkembang dengan cepat sehingga padfa PON ke-I tahun 1948 di Surakarta, Bola basket dapat dicantumkan dalam acara resmi. Persatuan Basket Ball seluruh Indonesia (PERBASI).

Pada permainan bola basket, untuk mendapatkan gerakan efektif dan efisien perlu didasarkan pada penguasaan keterampilan Bermain yang baik. Ketrampilan Bermain dalam permainan bola basket dapat dibagi menjadi enam, yaitu : teknik melempar dan menangkap, teknik menggiring bola, teknik menembak, teknik gerakan berporos, teknik tembakan lay up, dan merayah menurut Imam Sodikun yang dikutip oleh (Hapsari, 2013).

Pengertian motivasi menurut riduwan yang dikuti oleh (Aritonang, 2008) motivasi belajar adalah keseluruhan daya penggerak di dalam diri siswa yang menimbulkan kegiatan belajar, yang menjamin kelangsungan dari kegiatan belajar dan memberi arah pada kegiatan belajar, sehingga tujuan yang dikehendaki oleh subjek belajar itu dapat tercapai. Sedangkan minat belajar seperti menurut usman (Aritonang, 2008) yang dikutip William James mengatakan bahwa minat siswa merupakan faktor utama yang menentukan derajat keaktifan belajar siswa. 
Motivasi sendiri adalah wujud yang tidak nampak pada orang dan yang tidak bisa kita amati secara langsung. Yang dapat diamati adalah tingkah lakunya yang merupakan akibat atau manifestasi dari adanya motivasi pada diri orang itu. Kita sering dikungkungi oleh suatu konstelasi nilai-nilai (values) yang sewaktuwaktu dapat mendorong kita untuk bereaksi. Hal inilah yang menjadi salah satu sebab mengapa sukar sekali orang mengukur motivasi secara reliable, trutama apabila pengukuran, ini tergantung dan sering demikian dari kata hati (mood) Perasaan, atau verbalisasi orang yang kita ukur tersebut.

Sudarwan yang dikutip oleh (Suprihatin, 2015) motivasi diartikan sebagai kekuatan, dorongan, kebutuhan, semangat, tekanan, atau mekanisme psikologis yang mendorong seseorang atau sekelompok orang untuk mencapai prestasi tertentu sesuai dengan apa yang dikehendakinya

Sebagai dasar penelitian ini adalah hasil penelitian yang dilakukan oleh (Imanudin, 2014) yaitu adanya hubungan antara motivasi berprestasi dengan keterampilan bermain basket sehingga kesimpulan yang didapat ditarik adalah keinginan siswa untuk mendapatkan prestasi dalam bidang olahraga basket berhubungan dengan meningkatnya keterampilan bermain basket.

Sedangkan hasil penelitian yang dilakukan oleh (Antoni, 2017) menyatakan bahwa tidak ada korelasi yang signifikan tentang hubungan antara motivasi berprestasi dengan keterampilan bermain basket. Serta hasil penelitian tentang survei motivasi bermain basket (Yusuf \& Kartiko, 2007) dan (Hapsari, 2013) pengaruh motivasi belajar (Hamdu \& Agustina, 2011), (Amin Kiswoyowati, 2011) dan (Oktavian \& Kartiko, 2015). Dari perbedaan hasil dari penelitian diatas serta hasil penleitian eksperimen serta studi deskriptif yang sudah dilakukan juga oleh peneliti sebelumnya maka peneliti termotivasi untuk melakukan penelitian mengenai minat bermain bola basket pada anak sma karena minat belajar merupakan suatu kesatuan dari motivasi belajar yang perlu untuk dikaji secara gamblang.

\section{METODE PENELITIAN (The method)}

Dalam penelitian ini menggunakan metode survei yaitu penelitian yang mengambil sampel dari suatu populasi dan menggunakan kuesioner sebagai alat 
pengumpulan data yang pokok (Singarimbuan, M. S, 2008). Jenis penelitian ini adalah penelitian yang bersifat deskriptif. Dalam penelitian ini bisa dikatakan bahwa jenis penelitian deskriptif merupakan jenis penelitian yang mengisyaratkan pada penelitian kualitatif, dengan variabel-variabel abstrak seperti pendapat, persepsi, sikap, prestasi, motivasi dan lain-lain. Dan biasanya berusaha untuk mengungkapkan jawaban melalui pertanyaan apa, bagaimana, berapa dan bukan pertanyaan mengapa.

Tujuan utamanya adalah mengumpulkan informasi tentang variabel, bukan informasi tentang individu-individu. Dengan demikian pertanyaan-pertanyaannya disusun untuk memberikan informasi tentang variabel-variabel dan bukan untuk menghubungkan satu variabel dengan variabel yang lainnya. Sekalipun informasi tersebut menunjukan adanya hubungan antara variabel. Pertanyaan lebih bersifat memancing informasi untuk pemecahan masalah. Teknik yang digunakan adalah dengan menggunakan kuisioner atau angket dan dokumentasi. Angket penelitian ini berupa pertanyaan-pertanyaan yang berurusan dengan satu topik tunggal atau satu topik yang saling berkaitan, yang harus dijawab oleh subjek Angket yang dimaksud adalah berisi pertanyaan-pertanyaan yang menyangkut tentang motivasi, khususnya tentang motivasi bermain bola basket di Sekolah Menengah Atas. Angket tersebut diisi oleh siswa di sekolah yang menjadi objek penelitian dan diketahui oleh kepala sekolah yang bersangkutan.

Teknik yang digunakan adalah dengan menggunakan kuisioner atau angket dan dokumentasi. Angket penelitian ini berupa pertanyaan-pertanyaan yang berurusan dengan satu topik tunggal atau satu topik yang saling berkaitan, yang harus dijawab oleh subjek Angket yang dimaksud adalah berisi pertanyaanpertanyaan yang menyangkut tentang motivasi, khususnya tentang motivasi bermain bola basket di Sekolah Menengah Atas. Angket tersebut diisi oleh siswa di sekolah yang menjadi objek penelitian dan diketahui oleh kepala sekolah yang bersangkutan.

Angket juga memiliki keuntungan dan kelemahan sebagai alat pengumpulan data dalam suatu penelitian. Keuntungan angket adalah tidak memerlukannya kehadiran peneliti, dapat dibagikan secara serentak kepada responden, dapat dijawab oleh responden menurut kecepatannya masing-masing, menurut waktu 
senggang mereka, dapat dibuat anonim sehingga responden tidak malu-malu menjawab dan dapat dibuat standar sehingga semua responden dapat diberi pertanyaan yang benar-benar sama.

Sedangkan kelemahannya angket adalah responden sering tidak teliti dalam menjawab sehingga ada pertanyaan yang terlewati tidak di jawab sering sukar dicari validitasnya, walaupun dibuat anonim kadang-kadang responden dengan sengaja memberikan jawaban yang tidak jujur. Angket adalah sejumlah pertanyan atau peryataan tertulis yang digunakan untuk memproleh informasi dari responden dalam arti laporan tentang dirinya atau hal yang ia ketahui (Arikunto, 2002). Berdasarkan pengertian diatas, maka dapat disimpulkan bahwa angket adalah suatu tehnik pengumpulan data yang dipergunakan adalah daftar pertanyaan tertulis yang akan dijawab oleh responden. Adapun penilain item pertanyaan yang diberi bobot sebagai berikut (Sugiyono, 1997) : Jawaban sangat setuju $=4$, setuju $=3$, tidak setuju $=2$, sangat tidak setuju $=1$.

Angket juga memiliki keuntungan dan kelemahan sebagai alat pengumpulan data dalam suatu penelitian. Keuntungan angket adalah tidak memerlukannya kehadiran peneliti, dapat dibagikan secara serentak kepada responden, dapat dijawab oleh responden menurut kecepatannya masing-masing, menurut waktu senggang mereka, dapat dibuat anonim sehingga responden tidak malu-malu menjawab dan dapat dibuat standar sehingga semua responden dapat diberi pertanyaan yang benar-benar sama.

Sedangkan kelemahannya angket adalah responden sering tidak teliti dalam menjawab sehingga ada pertanyaan yang terlewati tidak di jawab sering sukar dicari validitasnya, walaupun dibuat anonim kadang-kadang responden dengan sengaja memberikan jawaban yang tidak jujur. Angket adalah sejumlah pertanyan atau peryataan tertulis yang digunakan untuk memproleh informasi dari responden dalam arti laporan tentang dirinya atau hal yang ia ketahui (Arikunto, 2002). Berdasarkan pengertian diatas, maka dapat disimpulkan bahwa angket adalah suatu tehnik pengumpulan data yang dipergunakan adalah daftar pertanyaan tertulis yang akan dijawab oleh responden.

Analisis data merupakan bagian yang sangat penting dalam penelitian sebab dengan adanya analisis data, Maka hipotesis yang ditetapkan bisa diuji 
kebenarannya untuk selanjutnya dapat diambil suatu kesimpulan. Tehnik analis data dalam penelitian ini menggunakan tehnik analisis data deskriptif. Sedangkan perhitungan dalam angket menggunakan deskriptif prosesntase cara perhitungan analisis data, mencari besarnya frekuensi Relative persentase. Dengan rumus sebagai berikut (Arikunto, 2002);

\section{$\mathrm{P}=\mathrm{F} / \mathrm{N} .100 \%$}

Keterangan:

$\mathrm{P} \quad=$ Persentase yang dicari

$\mathrm{F} \quad=$ Frekuensi penguatan

$\mathrm{N} \quad=$ Jumlah responden

\section{HASIL \& PEMBAHASAN (The result of the study)}

Analisis statistik deskriptif dimaksud Untuk mengetahui gambaran secara umum data hasil penelitian. Hasil analisis deskriptif data motivasi bermain bola basket siswa SMA Negeri 12 Makassar disusun sebagai berikut:

1. Untuk data motivasi bermain bola basket siswa SMA Negeri 12 Makassar, diperoleh nilai mean 86.0000, dengan median 86.5000, variance 75.448 , standar deviasi 8.68610, range 46.00, minimum 69.00, maximum 115.00, Sum 2580.00

2. Angka persentil nilai motivasi 30 orang siswa adalah : $25 \%$ memiliki motivasi yang rendah dengan nilai 82.0000 , 50\% memiliki motivasi yang sedang dengan nilai 86.5000 , dan $75 \%$ memiliki motivasi yang tinggi dengan nilai 90.2500 dalam berolahraga bola basket.

Berdasarkan pernyataan angket yang menyatakan bahwa 1) dalam melakukan Olahraga basket, dapat membuat tubuh kita menjadi sehat dan bugar dari 30 responden diperoleh jawaban sangat setuju sebanyak 9 orang atau 31,00\%. setuju sebanyak 21 Orang atau 69,9\%. Tidak setuju sebanyak 0 Orang atau 0\% dan jawaban sangat tidak setuju sebanyak 0 orang atau 0\%,2) Saya melakukan Olahraga bola basket untuk kesehatan dari 30 responden diperoleh jawaban sangat setuju sebanyak 1 orang atau 3,30\%. setuju sebanyak 22 Orang atau 73,30\%. Tidak setuju sebanyak 7 Orang atau 23,30\% dan jawaban sangat tidak setuju 
sebanyak 0 orang atau $0 \%, 3$ ) tanpa adanya fisik dan mental yang baik, maka kita tidak dapat melakukan olahraga basket dengan maksimal dari 30 responden diperoleh jawaban sangat setuju sebanyak 8 orang atau $26,60 \%$. setuju sebanyak 16 orang atau 53,30\%. Tidak setuju sebanyak 5 Orang atau 16,68.\% dan jawaban sangat tidak setuju sebanyak 1 orang atau 3,30\%

Berdasarkan pernyataan angket yang menyatakan 3) bahwa apabila fisik dan mental terganggu, maka kita tidak dapat melakukan olahraga bola basket dengan sungguh-sungguh dari 30 responden diperoleh jawaban sangat setuju sebanyak 11 orang atau 36,60\%. setuju sebanyak 14 Orang atau 46,60\%. Tidak setuju sebanyak 4 Orang atau 13,30\% dan jawaban sangat tidak setuju sebanyak 1 orang atau 3,30\%, 4) fisik dan mental seseorang sangat berperan penting dalam melakukan olahraga bola basket dari 30 responden diperoleh jawaban sangat setuju sebanyak 10 orang atau 3,30\%. setuju sebanyak 18 Orang atau 59,90\%. Tidak setuju sebanyak 2 Orang atau $6,60 . \%$ dan jawaban sangat tidak setuju sebanyak 0 orang atau $3,30 \%, 5)$ saya sangat senang melakukan olahraga bola basket karena lingkungan yang menyenangkan dari 30 responden diperoleh jawaban sangat setuju sebanyak 2 orang atau 6,60\%. setuju sebanyak 15 Orang atau 56,60\%. Tidak setuju sebanyak 12 Orang atau 23,30\% dan jawaban sangat tidak setuju sebanyak 1 orang atau 3,30\%

Berdasarkan pernyataan angket yang menyatakan bahwa 6) saya tanpa adanya lingkungan yang sehat dan tempat yang baik, maka seseorangtidak dapat berolahraga basket dengan maksimal dari 30 responden diperoleh jawaban sangat setuju sebanyak 5 orang atau 16,68\%. setuju sebanyak 17 Orang atau 56,60\%. Tidak setuju sebanyak 7 Orang atau 23,30\% dan jawaban sangat tidak setuju sebanyak 1 orang atau 3,30\%, 7) lingkungan yang sehat, sangat berperan penting dalam melakukan olahraga bola basket dari 30 responden diperoleh jawaban sangat setuju sebanyak 8 orang atau 26,60\%. setuju sebanyak 15 Orang atau 49,90\%. Tidak setuju sebanyak 7 Orang atau 23,00\% dan jawaban sangat tidak setuju sebanyak 0 orang atau $0 \%$.

Untuk kepentingan pengujian hipotesis maka dilakukan analisis motivasi bermain bola basket siswa SMA Negeri 12 Makassar. Hasil perhitungan secara lengkapnya dapat dilihat dari rumus yang digunakan adalah presentase, maka 
akan diketahui sejauhmana motivasi bermain bola basket siswa SMA Negeri 12 Makassar sebagai berikut :

$$
\begin{aligned}
\% & =\frac{j u m l a h \text { nilai yang diperoleh }}{\text { Jumlah item } x \text { jumlah skor ideal } x \text { jumlah responden }} \\
\% & =\frac{2580}{30 \times 4 \times 30} \times 100 \\
\% & =\frac{2580}{3600} \times 100 \\
\% & =71,66
\end{aligned}
$$

Dari hasil analisis data yang telah dirumuskan diatas, maka penulis menyimpulkan bahwa motivasi bermain bola basket siswa SMA Negeri 12 Makassar adalah menunjukkan kategori sedang dengan hasil yang diperoleh sebesar 71,66. Hasil analisis data maupun pengujian hipotesis yang telah dikemukakan menunjukkan bahwa hipotesis yang diajukan dalam penelitian ini diterima. Namun hasil ini masih perlu pembahasan lebih lanjut untuk memberikan interprestasi yang lebih mendalam tentang hasil penelitian yang peroleh dikaitkan dengan teori-teori maupun kerangka berfikir yang telah dikemukakan sebelumnya.

Bila mengamati tingkat motivasi bermain bola basket siswa SMA Negeri 12 Makassar, maka dapat dikatakan bahwa motivasi bermain bola basket menunjukkan kategori sedang. Hal tersebut diperkuat dengan hasil analisis data dimana 71.66\% motivasi bermain bola basket siswa SMA Negeri 12 Makassar. Apabila hal ini dihubungkan dengan teori maupun kerangka berpikir yang telah dikemukakan sebelumnya, pada dasarnya mendukung hasil penelitian ini. Tinggi atau rendahnya motivasi seseorang dalam bermain bola basket sangat dipengaruhi oleh sehat fisik dan mental, lingkungan yang sehat dan menyenangkan, fasilitas lapangan dan alat yang baik untuk latihan, olahraga yang disesuaikan dengan bakat dan naluri, metode audio visual, metode mengajar. Seperti halnya bagi siswa SMA Negeri 12 Makassar, terdapat beberapa siswa yang lebih cenderung termotivasi bermain bolabasket. Begitu pun sebaliknya ada beberapa siswa yang lebih cenderung tidak termotivasi bermain bolabasket. 
Motivasi adalah proses-proses yang bermaksud untuk mendorong orang untuk bereaksi atau tidak untuk bereaksi dalam berbagai situasi. Dalam hal ini penyajian materi oleh guru pada saat memberikan materi olahraga basket sangat berperan selain itu faktor sarana dan prasarana, dukungan keluarga, juga sangat berperan. Kondisi sarana dan prasana di SMA Negeri 12 Makassar sangat tidak memadai ditambah kurangnya dukungan dari pihak birokrasi sekolah itu sendiri, hal tersebut sangat berpengaruhi terhadap minat siswa yang berakibat tidak termotivasinya sebahagian siswa dalam bermain bola basket.

Lebih jauh bahwa sesuai penelitian yang dilakukan (Nurina \& Sukoco, 2014) tentang peningkatan karakter siswa sma yang menunjukkan hasil yang positif melalui permainan bola basket menjadi hal yang sangat penting dalam mendukung hasil yang kami dapatkan dari penelitian ini. Bisa diartikan dengan karakter yang meningkat maka minat serta motivasi bermain basket dalam pembelajaran juga akan terpengaruh secara tidak langsung.

\section{KESIMPULAN (Conclusion)}

Berdasarkan hasil analisis data dan pembahasan, maka hasil penelitian ini dapat disimpulkan sebagai berikut : motivasi dalam bermain bola basket siswa SMA Negeri 12 Makassar menunjukkan kategori sedang. Hal tersebut karena dipengaruhi oleh faktor-faktor yang dapat mengurangi motivasi untuk bermain bola basket seperi sarana dan prasana, media pembelajaran, dukungan dari keluarga, dan lain-lain.

\section{DAFTAR RUJUKAN (Bibliography)}

Amin Kiswoyowati. (2011). PENGARUH MOTIVASI BELAJAR DAN KEGIATAN BELAJAR SISWA TERHADAP KECAKAPAN HIDUP SISWA. Jurnal Pendidikan Indonesia, Edisi Khus(1), 120-126.

Antoni, R. (2017). HUBUNGAN ANTARA MOTIVASI BERPRESTASI DENGAN KETERAMPILAN BERMAIN BOLA BASKET: Study korelasi pada team SMA labschool.

Arikunto, S. (2002). Metode Penelitan. Jakarta: Rineka Cipta.

Aritonang, K. T. (2008). Minat dan Motivasi dalam Meningkatkan Hasil Belajar Siswa. Jurnal Pendidikan Penabur, 7(10), 11-21. 
Hamdu, G., \& Agustina, L. (2011). PENGARUH MOTIVASI BELAJAR SISWA TERHADAP PESTASI BELAJAR IPA DI SEKOLAH DASAR. Jurnal Penelitian Pendidikan, 12(1), 81-86.

Hapsari, A. T. (2013). STATUS KETRAMPILAN BERMAIN BOLA BASKET PADA CLUB NBC ( NGALIYAN BASKETBALL CENTER ) KOTA SEMARANG.

Imanudin, M. T. (2014). HUBUNGAN TINGKAT KEBUGARAN DAN MOTIVASI BERPRESTASI DENGAN KETERAMPILAN BERMAIN BASKET: Studi Deskriptif Terhadap Siswa Ekstrakurikuler Basket Putra SMK Krangkeng.

Nurina, T., \& Sukoco, P. (2014). Upaya Peningkatan Karakter Siswa SMA dalam Permainan Bola Basket Melalui Model TPSR. Jurnal Keolahragaan, 2, 77-87.

Oktavian, O., \& Kartiko, D. C. (2015). PENGARUH PENYELENGGARAAN UNESA CUP BASKET TERHADAP MOTIVASI SISWA DALAM MENGIKUTI EKSTRAKURIKULER BOLA BASKET. Jurnal Pendidikan Olahraga Dan Kesehatan, 3(1), 132-134.

Singarimbuan, M. S, E. (2008). Metode Penelitian Survai. Cetakan Kedelapanbelas. Jakarta: LP3ES.

Sugiyono. (1997). Metode Penelitian Administrasi. Bandung: Alfabeta.

Suprihatin, S. (2015). UPAYA GURU DALAM MENINGKATKAN MOTIVASI BELAJAR SISWA. JURNAL PROMOSI Jurnal Pendidikan Ekonomi UM Metro, $3(1), 73-82$.

Yusuf, M., \& Kartiko, D. C. (2007). MOTIVASI SISWA DALAM MENGIKUTI KEGIATAN EKSTRAKURIKULER BOLA BASKET DI SMPN SEKECAMATAN KUTOREJO MOJOKERTO. Jurnal Pendidikan Olahraga Dan Kesehatan, 2(2), 493-500. 